\title{
KEPEMIMPINAN WANITA DALAM ISLAM
}

\author{
Patsun \\ patdawany@gmail.com \\ STAI Hasan Jufri Bawean
}

\section{Abstrak}

Kepemimpinan wanita dalam kancah politik menuai kontroversi di dalam Islam. Hal ini disebabkan oleh nas hadis sahih yang menyatakan bahwa suatu kaum tidak akan beruntung jikea dipimpin oleh wanita. Bagi ulama konservatif, akan memahami hadis tersebut apa adanya (tekstual). Namun bagi ulama yang moderat akan memahaminya dari sisi kontekstual. Agama Islam berpedoman kepada al-Qur'an dan hadis, oleh sebab itu, tidak adil kiranya jika hanya memotret dari sisi hadis saja dan mengesampingkan al-Qur'an. Artikel ini akan membahas tentang kepemimpinan wanita dari sisi al-Qur'an, hadis, biologis wanita dan sosiologis bangsa Indonesia. Kesimpulan artikel ini adalah al-Qur'an melegitimasi kepemimpinan wanita lewat kisah ratu Saba' (Bilqis). Hadis tentang kepemimpinan wanita dapat dipahami sebagai 'komentar' Nabi terhadap pergantian kepemimpinan di Persia dan memiliki muatan lokal-temporal. Wanita memiliki kelemahan biologis pada saat menstruasi dan hamil, kelemahan fisik dibandingkan laki-laki, kelemahan psikologis dan emosional. Sedangkan bangsa Indonesia sesungguhnya juga menganut paham patriarki. Jadi, kontestasi politik terbuka lebar bagi siapapun, tanpa harus membedabendakan jenis kelamin. Siapapun yang terbaik, dialah yang berhak menjadi pemimpin.

Kata kunci: Kepemimpinan wanita, al-Qur'an, hadis, sosialbudaya. 
Spiritualis, vol. 6, no. 1, Maret 2020| 96

\section{Pendahuluan}

Di Indonesia kontroversi mengenai kepemimpinan wanita pernah terjadi, khususnya pada saat Megawati Soekarno Putri mencalonkan diri sebagai Presiden Republik Indonesia tahun 2004 lalu. Saat itu, tidak jarang para ulama yang merasa kurang cocok dengan kepemimpinan seorang wanita. Ketidak-cocokan tersebut bukan tanpa alasan, sebab di dalam hadis sahih memang disebutkan bahwa suatu kaum tidak akan mendapatkan keberuntungan jika dipimpin oleh seorang wanita (HR. Bukhāri).

Selain pertimbangan dari segi teologis-normatif tersebut, kepemimpinan wanita memang menuai kontroversi dari berbagai hal. Mulai dari kekuatan fisik, biologis, bahkan mental emosional. Banyaknya pemimpin Islam dulu yang laki-laki, ditengarahi menjadi penyebab budaya patriarki. Hal ini diperparah oleh 'tiada ulama perempuan' yang brilian dalam mengarang kitab-kitab klasik. Imbasnya adalah Islam di cap sebagai agama yang 'memojokkan kaum wanita' dalam persoalan kepemimpinan.

Dalam sistem demokrasi seperti yang dianut oleh bangsa Indonesia, setiap orang memiliki kesempatan yang sama untuk menjadi pemimpin. Para kaum Hawa saat ini sudah banyak yang tampil dikancah politik, baik menjadi kepala desa, camat, kepala daerah, menteri, DPR hingga presiden. Persamaan hak dalam kontestasi politik, harusnya yang menjadi ukuran bukan jenis kelamin, tetapi kualitas diri. Tidak peduli laki-laki atau perempuan, asalkan ia memiliki kualitas diri yang dapat di andalkan, ia dapat menjadi pemimpin.

Disatu sisi Indonesia menganut paham demokrasi yang memberikan persamaan hak kepada setiap warga negaranya untuk menjadi pemimpin. Namun di sisi lain penduduk Indonesia mayoritas adalah muslim dan umat Islam meyakini bahwa yang dijadikan pijakan hukum adalah al-Qur'an dan hadis. Sementara hadis di atas dengan jelas melarang wanita untuk menjadi pemimpin. Namun apakah benar demikian? Apakah al-Qur'an tidak membicarakan kepemimpinan perempuan sama sekali? Artikel ini akan membahas kepemimpinan 
wanita ditinjau dari aspek teologis-normatif, fisik, biologis dan sosiokultural masyarakat Indonesia.

\section{Naș Qur’an}

Adanya larangan wanita sebagai pemimpin negara sebenarnya terdapat dalam hadis (akan di bahas setelah al-Qur'an). Namun sebelum masuk ke sana penulis akan menjelaskan tentang peran pemimpin wanita yanag dijelaskan dalam al-Qur'an. Sebab, sumber hukum dalam Islam adalah al-Qur'an terlebih dahulu dibandingkan hadis.

Sejauh yang penulis ketahui, di dalam al-Qur'an tidak terdapat satupun ayat secara eksplisit (sarih) yang melarang wanita untuk menjadi pemimpin dalam dunia politik. Justru sebaliknya, dalam persoalan kepemimpinan wanita, penulis menemukan keterangan ayat yang menjelaskan bahwa al-Qur'an justru 'melegalkannya'.

Legalitas al-Qur'an mengenai kepemimpinan wanita tertuang dalam sebuah kisah (qasas) yang tidak memiliki muatan perintah ataupun larangan. Akan tetapi kisah tersebut dapat dijadikan i ibrah, sebab tujuan dari setiap kisah al-Qur'an adalah 'ibrab-nya. ${ }^{1} \quad$ Pernyataan eksplisit al-Qur'an mengenai kepemimpinan wanita ada dalam kisah Ratu Saba (Ratu Bilqis) yang tertuang di dalam surah al-Naml [27]:2040.

Dikisahkan bahwa ratu Bilqis memiliki singgasana besar yang menyaingi kerajaan nabi Sulaymān. Lalu nabi Sulaymān mengadakan sayembara bagi siapapun yang sanggup memindahkan singgasana ratu Bilqis ke hadapannya? Namun al-Qur'an tidak menjelaskan secara eksplisit apakah sayembara tersebut berhadiah atau tidak. Meskipun demikian, sayembara itu tetap berjalan dan dimenangkan oleh seorang hamba yang saleh bernama 'Ạṣif bin Barkhiyā.

\footnotetext{
${ }^{1}$ Surah Yüsuf [12]: 111 laqad kāna fĭ qasasibim 'ibrah li uti al-albāb (telah ada di dalam kisah mereka suatu pelajaran bagi orang-orang yang mempunyai akal). Departemen Agama Republik Indonesia, al-Qur'an dan Terjemahnya. Surabaya: Pustaka Assalam, 2010, 334-335.

2 Abū al-Fidā' Ismā̄il bin 'Umar bin Kathir, Tafsìr al-Qur'-̄n al-Ažim. Beirut: Dār Taybah, 1999, vol. 6, 192.
} 
Saat itu, jin 'Ifrit - yang masih berada dalam penguasaan Nabi Sulaymān - menyatakan bahwa 'saya sanggup mendatangkan singgasana itu sebelum Anda (Sulaymān) berdiri dari tempat duduk'. Namun seorang hamba bernama 'A șif bin Barkhiyā menyatakan 'saya akan memindahkan singgasana itu sebelum matamu berkedip'. Setelah itu singgasana ratu Saba' berpindah di hadapan kerajaan nabi Sulaymān dengan sekejap mata.

Awal kisah ratu Saba' tersebut dimulai dari ketidak-hadiran burung Hud-hud saat 'diabsen' oleh nabi Sulaȳman. Saat itu semua bisa hadir kecuali burung Hud-hud. Namun keterlambatannya tersebut ternyata membawa berita besar yang ingin disampaikan kepada Sulā̄mān. Di dalam surah al-Naml [27] ayat 20-24 Allah berfirman yang artinya:

20. Dia (Sulaymān) memeriksa burung-burung lalu berkata: "Mengapa aku tidak melihat hud-hud [sejenis burung pelatuk], apakah dia termasuk yang tidak hadir. 21. Sunggub aku benar-benar akan mengazabnya dengan azab yang keras atau benar-benar menyembelihnya kecuali jika benar-benar dia datang kepadaku dengan alasan yang terang". 22. Maka tidak lama kemudian (datanglah Hud-bud), lalu ia berkata: "Aku telah mengetahui sesuatu yang kamu belum mengetahuinya; dan kubawa kepadamu dari negeri Saba suatu berita penting yang diyakini.

23. Sesunggubnya aku menjumpai seorang wanita [Bilqis] yang memerintah mereka, dan dia dianugerabi segala sesuatu serta mempunyai singgasana yang besar. 24. Aku mendapati dia dan kaumnya menyembah matahari, selain Allab; dan setan telab menjadikan mereka memandang indah perbuatan-perbuatan mereka lalu menghalangi mereka dari jalan (Allab), sehingga mereka tidak dapat petunjuk.

Kisah di dalam al-Qur'an ini paling tidak memberikan bukti bahwa ada kepemimpinan wanita di dalam al-Qur'an. Allah tidak melarangnya juga tidak memberikan perintah supaya memilih pemimpin wanita. Namun yang menjadi penekanan di dalam ayat ini adalah tentang ghibah (menggunjing) yang dilakukan oleh Hud-hud bahwa ratu tersebut tidak beriman yang ditandai dengan 'menyembah matahari'. 
Namun pada akhirnya ratu Bilqis mengakui akan kehebatan nabi Sulaymān dan menyatakan mengikuti agama Sulaymān dengan menyembah Allah semata.

\section{Memahami Hadis Misoginis}

Dalam hal ini penulis akan mencantumkan dua hadis yang akan digunakan sebagai analisis tentang kepemimpinan wanita, yaitu bahwa wanita dinilai lemah akalnya dan suatu kaum tidak beruntung jika dipimpin oleh wanita. Pertama, kecurigaan awalnya adalah terdapat hadis yang menerangkan bahwa akal wanita itu separuh laki-laki. Pernyataan tersebut memang benar adanya di dalam hadis sahih riwayat Bukhāri, akan tetapi pemahaman dari hadis tersebut belum lengkap, karena ketika pemahaman hadis tersebut lengkap akan memberikan makna yang berbeda. Berikut adalah teks lengkap mengenai hadis yang menyatakan bahwa akal wanita adalah separuh laki-laki:

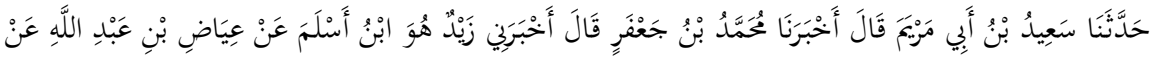

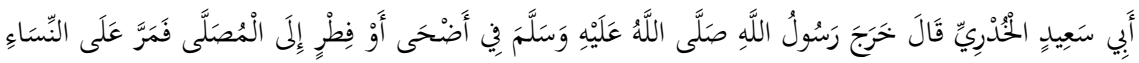

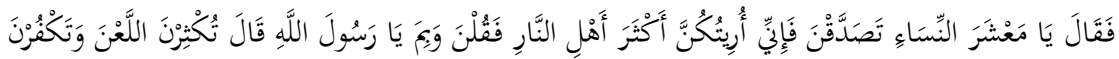

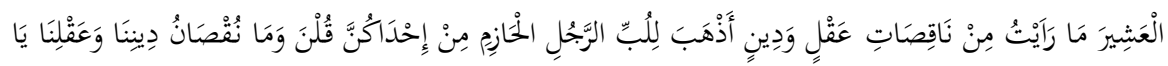

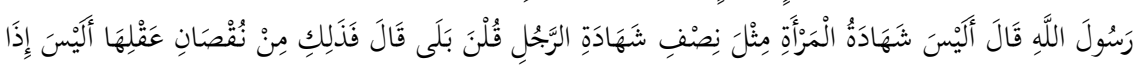

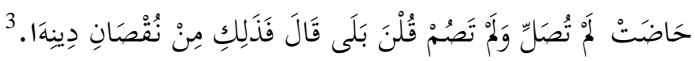

Telah menceritakan kepada kami Sa $\bar{i}$ id bin Abi Maryam berkata, telah mengabarkan kepada kami Muhammad bin Ja'far berkata, telah mengabarkan kepadaku Zayd -yaitu Ibnu Aslam- dari 'Iyāọ bin 'Abdullah dari Abū Sa ${ }^{\bar{T}} \mathrm{i}$ al-Khudri ia berkata, "Rasulullah saw. pada hari raya 'Idul Adha atau Fitri keluar menuju tempat shalat, beliau melewati para wanita seraya bersabda: "Wahai para wanita! Hendaklah kalian bersedekah, sebab diperlihatkan kepadaku bahwa kalian adalah

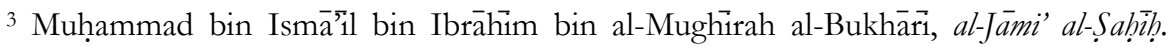
Kairo: Dār al-Shu'ab, 1987. 
yang paling banyak menghuni neraka." Kami bertanya, "Apa sebabnya wahai Rasulullah?" beliau menjawab: "Kalian banyak melaknat dan banyak mengingkari pemberian suami. Dan aku tidak pernah melihat dari tulang laki-laki yang akalnya lebih cepat hilang dan lemah agamanya selain kalian." Kami bertanya lagi, "Wahai Rasulullah, apa tanda dari kurangnya akal dan lemahnya agama?" Beliau menjawab: "Bukankah persaksian seorang wanita setengah dari persaksian laki-laki?" Kami jawab, "Benar." Beliau berkata lagi: "Itulah kekurangan akalnya. Bukankah seorang wanita bila dia sedang haid dia tidak shalat dan puasa?" Kami jawab, "Benar." Beliau berkata: "Itulah kekurangan agamanya.

Hadis ini memang memberikan kesan 'memojokkan wanita' dari berbagai sisi. Namun penulis hanya akan menjelaskan tentang aspek wanita yang kurang akalnya. Di dalam hadis ini sebenranya sudah jelas bahwa yang dimaksud kurang akalnya adalah karena kesaksian wanita itu setengah laki-laki. Hal ini terkait dengan surah al-Baqarah [2] ayat 282 yang artinya ... jika yang berhutang itu orang yang lemab akalnya atau lemah (keadaannya) atau dia sendiri tidak mampu menuliskan, maka hendaklah walinya menuliskan dengan jujur, dan persaksikanlah dengan dua orang saksi dari orang-orang lelaki (di antaramu). Jikea tidak ada dua orang lelaki, maka (boleh) seorang lelaki dan dua orang perempuan dari saksi-saksi yang kamu ridhai, supaya jika seorang lupa maka yang seorang mengingatkannya. Janganlah saksisaksi itu enggan (memberi keterangan) apabila mereka dipanggil.

Konteks ayat ini membicarakan tentang transaksi yang tidak langsung (hutang). Maka di saat demikian transaski itu harus ada saksi tertulis dan saksi mata. Saksi mata inilah yang menjelaskan satu laki-laki dan dua wanita. Jika melihat dari tujuan persaksian itu adalah supaya untuk mengingatkan satu sama lain apabila salah satunya lupa. Sedangkan yang kedua tujuannya adalah agar si saksi bisa hadir saat dipanggil untuk memberikan persaksian. Namun apabila salah satunya berhalangan, maka saksi yang lain masih bisa mewakili.

Kondisi fisik-biologis wanita berbeda dengan laki-laki. Wanita bisa mengandung dan melahirkan. Hal ini menjadi kendala manakala si wanita tersebut dijadikan saksi dan mengharuskannya untuk hadir dalam 
persaksian itu. Jadi, penentuan dua orang wanita untuk menjadi saksi tersebut untuk mengantisipasi agar tetap ada yang bisa memberikan persaksian saat dibutuhkan jika salah satu dari saksi itu berhalangan seperti sedang hamil atau melahirkan.

Sedangkan kekurangan dalam masalah agama juga terkait dengan persoalan biologis. Wanita memang diharamkan untuk melakukan ibadah tertentu pada saat ia nifas atau haid. Semua itu bukan keinginan wanita, tetapi 'keinginan Tuhan'. Andaikata diperbolehkan untuk memilih, tentu semua wanita ingin bebas dari 'halangan' itu dan disiplin beribadah. Jika itu sudah ketetapan Tuhan, apakah lantas kita 'menyalahkan 'Tuhan' karena dia tidak bisa beribadah.

Dalam konteks ini bisa jadi maknanya adalah wanita tersebut kurang agamanya karena berhalangan untuk beribadah ditinjau dari aspek kuantitas, bukan kualitas. Sebab yang dapat mengukur kualitas ibadah seseorang hanyalah Allah swt. Oleh karena itu tidak dapat digeneralisir bahwa wanita kurang agamanya berarti kurang ketaatannya. Tetapi pemahamannya adalah hanya berkurang kuantitasnya dan kekurangan kuantitas ibadah tersebut atas kehendak Allah, bukan kehendak wanita itu sendiri. Jadi, kekurangan akal dan agama dalam persoalan ini tidak menjadi penghalang untuk menjadi pemimpin.

Kedua, hadis tentang wanita yang menjadi pemimpin. Al-Bukhāri dalam hadis sahihnya menyatakan bahwa:

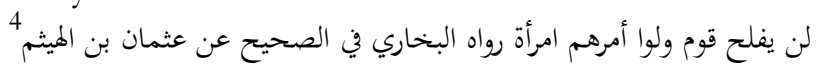

Tidak akan menemui keberuntungan suatu kaum yang dipimpin oleh seorang wanita (HR. Bukhāri dari Uthmān bin Haitham)

Ada sebagian ulama yang memahami nas hadis ini secara tekstual sehingga implikaisnya adalah mereka mengharamkan para wanita untuk menjadi kepala negara ataupun pemimpin lembaga besar.

4 Muḥammad bin Ismā̄il Abū 'Abd Allāh al-Bukhāri, al-Jāmi' al-Ṣaḅị̣ al-Mukhtasarar (Beirut: Dār Ibn Kathīr al-Yamāmah, 1987), Nomor Hadis 4163. Muhammad bin '̇̀̄ā

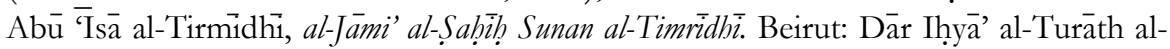
'Arabi, t. th. Vol. 4, 527. Aḥmad bin Shu'ayb Abū 'Abd al-Raḥmān al-Nasā̄ì, alMujtabā min al-Sunan. Halb: Maktab al-Maṭbū'àt al-Islāmìiyah, t. th. Vol. 8, 227. 
Pemahaman ini tentunya kurang tepat apabila melihat hadis tersebut dari sisi yang lain, yaitu dari sisi konteksnya.

Konteks hadis ini sangat kental dengan suasana politik pada masa itu. Kisah nabi Muhammad yang mengirimkan surat kepada kerajaan Kisra yang di tolak dengan merobek-robek isi surat itu sedikit banyak juga menjadi sebab terjadinya hadis ini. Hadis ini terjadi pada saat Nabi mendengar dari para sahabat, bahwa ada pengangkatan ratu Persia pada tahun $9 \mathrm{H}$. Padahal menurut tradisi Persia yang sudah berjalan, pengangkatan kepala negara adalah seorang laki-laki.

Pengangkatan itu dinilai menyalahi kebiasaan Persia karena sebelumnya yang menjadi kepala negara adalah laki-laki. Nama wanita itu adalah Buwaran binti Svarawaih bin Kisra bin Barwaiz. Dia di angkat sebagai ratu Kisra setelah terjadi keributan-keributan yang menyebabkan banyak terjadi pembunuhan dalam rangka suksesi kepala negara. Ketika sang raja meninggal dunia, Buwaran sebenarnya memiliki saudara laki-laki. Namun, iklim politik yang begitu memanas saat perebutan kekuasaan itu, menyebabkan saudara laki-laki Buwaran terbunuh sehingga Buwaran dinobatkan sebagai ratu Kisra. ${ }^{5}$

Dalam catatan sejarah, orang yang dikirimi surat oleh Nabi untuk diajak memeluk Islam adalah kakeknya Buwaran yang menolak ajakan Nabi dan justru merobek-robek surat Nabi. Pada akhirnya Nabi berdoa kepada Allah agar kerajaan Kisra di robek-robek pula. Tidak berselang lama setelah doa Nabi, Kisra memanas dan terjadilah peristiwa seperti yang penulis ceritakan di atas.

Nabi bersabda bahwa "suatu kaum tidak akan mendapatkan keberuntungan jike dipimpin oleh seorang wanita". Pada saat itu derajat kaum wanita tidaklah seperti sekarang ini, mereka tidak disegani, tidak berwibawa dan sebagainya. Sedangkan tipikal pemimpin sejati adalah yang berwibawa dan disegani. Dengan demikian, jika tidak disegani dan tidak berwibawa, maka kaum tersebut terancam kehancuran. Dalam konteks inilah Nabi menyatakan bahwa "Suatu kaum tidak akan beruntung

${ }^{5}$ Syuhudi Isma'il, Hadis Nabi yang Tekstual dan Kontekstual: Telaah Ma'ani al-Hadith tentang Ajaran Islam yang Universal, Temporal dan Lokal. Jakarta: Bulan Bintang, t. th, 6467. 
jika dipimpin oleh perempuan." Dengan mengacu kepada kejadian dalam hadis ini maka dapat disimpulkan bahwa hadis tersebut memiliki sifat local-temporal dan tidak universal.

\section{Kontekstualisasi}

Dalam konteks sekarang, sudah banyak wanita yang memiliki prestasi luar biasa, bahkan melebihi kaum pria. Oleh sebab itu, di era sekarang, yang menjadi tolak ukur bukanlah jenis kelamin melainkan kualitas diri. Siapa saja yang dinilai mampu membawa masyarakat menjadi lebih baik, tidak peduli ia pria atau wanita, maka dialah orang yang tepat untuk memimpin suatu masyarakat.

Berapa banyak kaum wanita yang terbukti sukses dalam menjalankan tugasnya sebagai seorang pemimpin. Baik Presiden, mentri, gubernur, wali kota, bupati dan segaianya. Kepemimpinan itu bukanlah ditentukan oleh gender, malainkan oleh kualitas diri. Namanama berikut paling tidak memberikan bukti bahwa kepemimpinan wanita tidak dapat diremehkan.

Tri Rismaharini, walikota Surabaya 2 periode yang menjabat hingga 2021 mendatang dan menyabet gelar walikota terbaik di dunia. Khofifah Indarparawansa, menteri sosial era presiden Joko Widodo yang kini menjabat sebagai Gubernur Jawa Timur. Puput Tantriana Sari bupati pertahana Probolinggo yang menjabat sejak 2013 dan pada 2018 lalu mendapatkan suara $56 \%$.

Mundjidah Wahab, Bupati Jombang periode 2013-2018; Ika Puspitasari, walikota Mojokerto periode 2018-2023; Anna Muawanah, bupati Bojonegoro periode 2018-2023; Faida, bupati Jember periode 2016-2021. Haryanti Sutrisno, bupati Kediri 2 periode hingga tahun 2021. Dewanti Rumpoko, walikota Batu hingga 2022. Rukmini Buchori, walikota Probolinggo periode 2009-2014.

Semua nama tersebut hanyalah dari satu tipologi kepemimpinan, yaitu kepala daerah yang ada di Jawa. Belum tipologi yang lain seperti camat, kepala desa, menteri, dan kepala daerah lain di luar pulau Jawa. Selain pemimpin politik, pemimpin lembaga pendidikan tinggi juga banyak diduduki oleh kaum wanita. 
Reini Wirahadikusumah adalah rektor Institut Teknologi Bandung periode 2020-2025; Prof. Ir. Dwikorita Karnawati, M. Sc. Ph. D Rektor Universitas Gajah Mada periode 2014-2017; Prof. Dr. Amany Burhanudin Umar Lubis, Lc. MA, rektor UIN Syarif Hidayatullah Jakarta periode 2019-2023; Prof. Dr. Rina Indiastuti, M. SIE, rektor Universitas Padjajaran 2019-2024 dan lain sebagainya.

\section{Status Hukum Hadis Kepemimpinan Wanita}

Hadis di atas berstatus sahih baik dari riwayat Bukhāri maupun yang lainnya. Namun yang menjadi pertanyaan adalah apakah status hukum tersebut harus diberlakukan di zaman sekarang? Tidak. Karena hadis ini tidak semuanya memiliki muatan yang bersifat universal. Ada hadis yang bermuatan lokal dan temporal, ada pula yang bermuatan universal. Walaupun hadis ini sahih, akan tetapi muatan hukumnya bersifat lokal-temporal. Lokal dalam artian untuk Kisra pada saat itu dan temporal adalah berkaitan dengan 'komentar Nabi' dalam persoal an peralihan kekuasaan Kisra pada sat itu.

Contoh lain hadis memiliki muatan lokal-temporal adalah 'alAimmah min Quraish' (Imam [pemimpin] itu dari Quraish). ${ }^{6}$ Hadis ini statusnya sahih lighairih, namun apa jadinya jika hadis tersebut diberlakukan di sekitar kita. Jika tidak ada orang Quraish, apakah tidak diperlukan pemimpin? Tentu tetap diperlukan, sebab suatu daerah harus ada yang memimpin. Jadi, status hukum hadis mengenai kepemimpinan wanita di atas harus di pahami dan diberlakukan secara kontesktual dan temporal.

Walaupun hadis tentang kepemimpinan wanita di atas bermuatan temporal, maka hendaknya mempertimbangkan hal berikut manakala pemimpin itu adalah wanita. Hadis Nabi bisa saja diberlakukan di masa sekarang jika saja melihat berbagai pertimbangan sebagai berikut:

6 HR. Aḥmad. Status hadis ini adalah sahih lighairih ditinjau dari segi sanad dan shawāhid. Namun jika ditinjau dari satu jalur saja, maka akan berstatus da'if karena di dalamnya ada seorang perawi yang bernama Bakir bin Wahab al-Juzri yang dinilai kurang cakap. 
Pertama, berkaitan dengan mental. Secara umum, mental wanita di bawah pria. Baik mengenai ketegaran dalam menghadapi cobaan, saat menghadapi perkara-perkara sulit atau perkara lain. Kaum pria lebih kuat dibandingkan dengan kaum wanita. Contoh sederhana misalnya pada saat mengemudikan mobil yang akan menabrak, kaum wanita biasanya lebih mementingkan untuk menutup mata daripada melihat kedepan dan mengatur strategi untuk menghindar dari tambrakan tersebut. Apalagi sebagian besar lebih mendahulukan menjerit daripada fokus untuk menghindari suatu hal. Itu artinya, secara mental bawaan, kaum wanita memang di bawah kaum pria.

Karena mental yang memang kurang kuat jika dibandingkan dengan kaum pria, maka tidak aneh jika menghadapi situasi-situasi sulit kaum wanita sering panik dan berdampak pada melakukan keputusan yang kurang tepat. Pada saat-saat mengalami persoalan berat misalnya, kaum wanita juga sering mangandalkan air mata sebagai senjatanya, padahal, urusan-urusan negara sangatlah berat dan dituntut untuk selalu tegar dan tegas dalam menghadapi berbagai persoalan agar keputusan yang dihasilkan sesuai dengan harapan rakyatnya.

Kedua, kelemahan fisik. Kekuatan fisik wanita rata-rata di bawah kaum pria. Perbedaan ini bisa dilihat dari segi tinggi badan, kekuatan fisik dan yang lainnya. Untuk tugas-tugas berat semisal berjalan jauh bahkan ke tempat-tempat yang terpencil dan menuntut untuk kekuatan fisik, tentu hal yang demikian akan menjadi kendala manakala pemimpinnya adalah wanita dan hal ini minim terjadi pada pria, sebab secara fisik rata-rata pria di atas wanita. Selain itu, secara biologis memang terdapat perbedaan antara wanita dengan pria.

Ketiga, secara biologis. Jika wanita menjadi kepala negara, maka ia akan sedikit terganggu pada saat menstruasi. Karena pada saat terjadi menstruasi, ia akan mengalami perubahan hormon dan emosi, dalam keadaan seperti itu akan sulit kiranya di dalam memutuskan perkaraperkara rumit. Jika ia hamil, maka akan banyak waktu yang tersita. Karena ia harus istirahat beberapa bulan. Jika hanya satu kali hamil, mungkin saja mudah. Tetapi jika berkali-kali?

Apakah suatu negara akan berhenti kebijakannya hanya karena sang presiden sedang hamil? Apakah suatu negara akan menggagalkan 
pertemuan-pertemuan penting hanya karena sang kepala negara melahirkan? Apakah suatu roda pemerintahan akan berhenti sejenak karena alasan kepala pemerintahannya dalam keadaan menstruasi?

Semua itu adalah tabiat wanita yang berbeda dengan pria. Pada saat-saat seperti itulah secara fisik wanita akan terganggu manakala harus melakukan tugas negara yang begitu berat. Jadi, dalam masalah ini laki-laki dan wanita untuk menjadi kepala negara bukanlah dipandang dari sisi boleh dan tidak boleh, akan tetapi dari sisi baik dan tidaknya.

\section{Persoalan Patriarki}

Para kaum feminis menuduh bahwa ketidak-berpihakan ajaran Islam kaum wanita bukan hanya didasarkan oleh kesalahan di dalam memahami hadis misoginis saja, akan tetapi para ulama terdahulu juga dituduh tidak berpihak kepada kaum wanita. Hal ini ditengarai oleh ketiadaan ulama perempuan yang menorehkan kitab-kitab turath dan juga ketiadaan pemimpin perempuan di dalam Islam pasca Rasulullah saw. wafat. Jadi, dua hal tersebut dinilai semakin memojokkan kaum perempuan di dalam meraih kepemimpinan dalam berbagai bidang. Sebelum lebih jauh mengkritik tentang ulama salaf, alangkah baiknya seseorang introspeksi diri terlebih dahulu dalam persoalan partiarki ini.

Hukum sosial Jawa sebenarnya juga mengakomodir patriarki (dominasi kaum laki-laki) tetapi memang kita sendiri kurang menyadari. Misalnya pada saat sang istri menjadi kepala desa (lurah), apakah sang suami di panggil pak lurah? Tidak. Jika sang istri menjadi presiden, apakah sang suami di panggil pak presiden?. Tidak. Namun sebaliknya, jika yang menjadi presiden adalah sang suami, maka sang istri juga akan mendapatkan gelar presiden itu, misalnya ibu presiden, ibu lurah dan sebagainya, padahal yang menjabat adalah suaminya. Itu artinya, sistem sosial kita sebenarnya juga mengamini patriarki, hanya saja ada motifmotif tertentu yang menyudutkan Islam, seoalah-olah Islam tidak memihak kepada kaum wanita. Padahal sistem sosial kita sebenarnya juga mendukung tentang hal itu. Oleh karenanya, perbedaan dalam hal menjadi seorang pemimpin ini bukan di landaskan jenis kelamin akan tetapi kualitas diri. 


\section{Kesimpulan}

Kepemimpinan wanita di dalam Islam harus dipotret dari sisi alQur'an terlebih dahulu dibandingkan dengan hadis. Sebab al-Qur'an adalah pijakan hukum pertama. Di dalam al-Qur'an terdapat kisah yang melegalkan kepemimpinan wanita, yaitu kisah ratu Saba' (Bilqis) di dalam surah al-Naml [27] ayat 20-40.

Hadis nabi yang menyatakan bahwa akal wanita adalah setengah kaum pria harus dipahami dari segi kuantitas, bukan kualitas. Sedangkan hadis yang menyatakan bahwa suatau kaum tidak akan menemuai keberuntungan jika dipimpin oleh wanita adalah terkait komentar Nabi kepada kerajaan Kisra yang sedang mengalami pergantian kekuasaan oleh seorang wanita bernama Buwaran.

Hadis tersebut meskipun berstatus sahih, akan tetapi muatan hukum yang diandungnya hanyalah lokal-temporal, tidak universal. Oleh karena itu, pemahaman hadis tersebut tidak dapat diterapkan secara tekstual tetapi kontekstual. Jadi, dalam persoalan ini tidak ada halangan bagi seorang wanita untuk melangkah ke dunia politik.

Adanya kaum feminis yang menuduh bahwa para ulama dan pemimpin Islam pada masa lalu tidak ada yang wanita menyebabkan citra negatif terhadap Islam bahwa seakan-akan ajaran Islam membela kaum laki-laki saja dan memojokkan perempuan. Padahal sesungguhnya tidak demikian, justru orang Jawa bahkan Indonesia sendiri sebenarnya yang patriarki, akan tetapi tidak disadari. 


\section{DAFTAR PUSTAKA}

Bukhārì (al), Muhammad bin Ismāīl bin Ibrāhìm bin al-Mughirah. alJāmi' al-Ṣahịh. Kairo: Dār al-Shu'ab, 1987.

Departemen Agama Republik Indonesia, al-Qur'an dan Terjemahnya. Surabaya: Pustaka Assalam, 2010.

Ibnu Kathìr, Abū al-Fidā' Ismāīil bin 'Umar. Tafsì al-Qur'än al-Ažim. Beirut: Dār Ṭaybah, 1999.

Isma'il, Syuhudi. Hadis Nabi yang Tekstual dan Kontekstual: Telaah Ma'ani al-Hadith tentang Ajaran Islam yang Universal, Temporal dan Lokal. Jakarta: Bulan Bintang, t. th.

Nasā̄ì (al), Aḥmad bin Shu'ayb Abū 'Abd al-Raḥmān. al-Mujtabā min al-

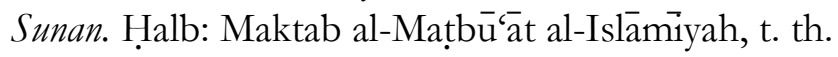

Tirmidhì (al), Muḥammad bin 'Isā Abū 'Isa. al-Jāmi’ al-Ṣahịh Sunan alTimrìdhì. Beirut: Dār Ihỳā' al-Turāth al-'Arabi, t. th. 